\title{
Estimated productivity of sugarcane through the Agro-Ecological Zone method
}

\author{
Jordana Moura Caetano $^{2 *}$ (D), José Alves Júnior ${ }^{2}$, Derblai Casaroli², Adão Wagner Pêgo Evangelista ${ }^{2}$
}

10.1590/0034-737X202168010001

\begin{abstract}
The estimate of the potential sugarcane productivity through agroclimatic models aids in the agricultural planning of the crops and the quantification of the yield for a given region. For these estimated values to be considered robust there is a need for validating the performance of such models in different areas and agricultural varieties. Hence, the aim of this study was to validate the Agro-Ecological Zone (AEZ) method with fifteen sugarcane varieties in the region of the Vale do São Patrício, state of Goiás, Brazil. We evaluated the data referring to the cane-plant (one-and-a-half-year sugarcane), as well as the first and second sugarcane ratoons (both with one-year cycles) in an irrigated and dry farming system. The productivities obtained in dry farming were corrected due to the occurrence of a water deficit in the crop. The results indicated that the AEZ method presented productivity estimates more satisfactory for the one-year cultivation cycles (ratoon cycles) for all varieties studied, with the model adjusting best to the $\mathrm{CTC} 15$ variety (RMSE $=8.70 \mathrm{tha}^{-1} ; \mathrm{MAE}=$ $\left.6.05 \mathrm{tha}^{-1} ; \mathrm{d}=0.99\right)$.
\end{abstract}

Keywords: bioenergy; water deficit; water balance; agricultural planning; harvest forecast.

\section{INTRODUCTION}

The enhancement of the sugarcane sector needs tools that aid in predicting yield in different regional scales, aiming at improving the productive process, collaborating with strategic decision-making throughout the harvest, and contributing with the continuity of development of the sector (Scarpari \& Beauclair, 2009).

The use of prediction models that consider soil, climate, and plant parameters in the agrosystem modeling is recommended for sugarcane by some authors (see Oliveira et al., 2012a; Caetano \& Casaroli, 2017) as it allows reliable productivity estimates. The sugarcane production system is high affected by climatic conditions (Loarie et al., 2011; Marafon, 2012; Oliveira et al., 2012a; Marin \& Carvalho, 2012). Among the climatic factors that determine sugarcane productivity are solar radiation, temperature, and water availability, which interfere with the accumulation of biomass at the stem (Inman-Bamber $e t$ al., 2002).
Specifically, sugarcane shows satisfactory growth when grown in areas exposed to solar energy from 18 to $36 \mathrm{MJ} \mathrm{m}^{-2} \mathrm{~d}^{-1}$, photoperiod between 10 and 14 hours (Monteiro, 2012) and air temperature between 25 and 35 ${ }^{\circ} \mathrm{C}$ (Doorenbos \& Kassam, 1979). The water demand for sugarcane is in the range of 1,500 to $2,500 \mathrm{~mm}$ evenly distributed during development (Doorenbos \& Kassam, 1979).

There are several prediction models in the scientific literature used to estimate the productivity of sugarcane, such as CANEGRO (Thompson, 1976), CANESIM (Singels \& Donaldson, 1998) and APSIM-Sugarcane (Bull \& Tovey, 1974). One of the most employed agrometeorological models for harvest forecasting and widely used with sugarcane is the Agro-Ecological Zone method by Food and Agriculture Organization - FAO (Doorenbos \& Kassam, 1979). This methodology stands out due to its low requirement of input data (e.g., meteorological and crop data), presenting results close to reality (Oliveira $e t$

\footnotetext{
Submitted on February $11^{\text {th }}, 2020$ and accepted on October 1 $15^{\text {th }}, 2020$.

${ }^{1}$ Universidade de Brasília, Faculdade de Agronomia e Medicina Veterinária, Brasília, Distrito Federal, Brazil. jordana.caetano@unb.br

${ }^{2}$ Universidade Federal de Goiás, Escola de Agronomia, Departamento de Engenharia de Biossistemas, Goiânia, Goiás, Brazil. jose.junior@pesquisador.cnpq.br; derblaicasaroli@yahoo.com.br; awpego@ @esquisador.cnpq.br

*Corresponding author: jordana.caetano@unb.br
} 
al., 2012b) and having as a premise the absence of limitations in terms of the mineral nutrition of the plants and damages caused by diseases and, or, pests (Barbieri \& Silva, 2008). However, the potential productivity estimated by this model may still be penalized by water deficit, optimizing the estimate of real productivity (Gouvêa et al., 2009).

The state of Goiás, Brazil, is the second leading national producer of sugarcane (Companhia Nacional de Abastecimento - Conab, 2020) and presents a vast potential for the expansion of this crop. This is due to the lower cost of lands when compared to traditional areas of occupation of the crop (e.g., São Paulo), besides the suitable terrain, infrastructure, and average distance to the main consumer markets (Silva \& Miziara, 2011). On the other hand, Goiás presents disadvantages compared to the state of São Paulo such as a more significant water deficit (Marin \& Nassif, 2013; Araújo et al., 2016), and difficulty in the adoption of varieties adapted to the edaphoclimatic conditions of the region (Campos et al., 2014a, 2014b).

In Goiás, the sugarcane varieties used commercially are still imported from breeding programs developed in other states, mainly São Paulo and Minas Gerais (Rede Interuniversitária para o Desenvolvimento do Setor Sucroalcooleiro - RIDESA, 2010). According to the sugarcane varietal census conducted by the Instituto Agronômico de Campinas (IAC), the most cultivated variety in the state of Goiás is RB86-7515, representing $20.1 \%$ of the varieties planted in the region. This variety was launched in the late 90s and developed, therefore, in the pre-mechanized period of planting and harvesting. However, the census also indicated that new varieties (for example, CTC4) are being incorporated, which means that genetic diversification and more modern materials are entering the fields (Braga Júnior et al., 2019).

The hypothesis for the study is: i) the Agro-Ecological Zone method is suitable to estimate the productivity of the sugarcane cultivated in state of Goiás. The aim this study was to apply the Agro-Ecological Zone method in different sugarcane varieties cultivated in the Cerrado of Goiás under irrigated and dry systems to determine which varieties have their productivities better estimated for the region of study, given that the knowledge of such data contributes to the validation of the performance of this model. Also, we investigated which variety presented superior productivity for the studied conditions, seeking to identify which one shows the best suitability to the region's climate.

\section{MATERIAL AND METHODS}

The experiment was conducted with fifteen commercial sugarcane varieties, with the collection of productivity data referring to the harvest years of 2011/ 12 (cane-plant), 2012/13 (first sugarcane ratoon), and 2013/14 (second sugarcane ratoon). The experimental area was located in the municipality of Goinésia, GO, Brazil (15²' 'S; 48 59'W; altitude of $580 \mathrm{~m}$ ), which has a climate of type Aw according to Köppen, denominated savanna tropical and characterized by a dry winter (MayOctober) and rainy summer (September-April). The municipality presents an average annual rainfall of 1,519 $\mathrm{mm}$. During the experiment, the average maximum and minimum air temperatures were 30.8 and $19.2{ }^{\circ} \mathrm{C}$, respectively, and the average accumulated rainfall per harvest year was 1,136.7 mm (Figure 1). Plants were cultivated in Oxisol Hapludox, corresponding to a Red Yellow Latosol distrophic (Empresa Brasileira de Pesquisa Agropecuária - Embrapa, 2006).

For installation of the experiment the area was prepared 180 days before. Soil chemical and physical analysis was made in the layers: $0-0.5$ and $0-0.60 \mathrm{~m}$, respectively. For reach base saturation of 50\%, dolomitic limestone was applied and incorporated with soil tillage (heavy harrow). Then, phosphate $\left(\mathrm{P}_{2} \mathrm{O}_{5}\right)$ and gypsum were applied, $100 \mathrm{~kg} \mathrm{ha}^{-1}$ and 2,250 kg ha-1, respectively, and incorporated with breaking of clods and with leveling disk harrow.

In sugarcane planting (April 29th, 2011) was applied $115 \mathrm{~kg} \mathrm{P}_{2} \mathrm{O}_{5}$ (triple super phosphate) $\mathrm{ha}^{-1}$ and $0.05 \mathrm{~kg} \mathrm{ha}^{-1}$ of Phipronil insecticide $800 \mathrm{WG}$ in furrow (deep of $0.35 \mathrm{~m}$ ), and used stalks with three vegetative buds in line. Then was applied irrigation depth of $40 \mathrm{~mm}$ to stimulate sugarcane growth.

In the harvest years of 2011/12 and 2012/13, the entire experimental area was irrigated with the objective of supplying $50 \%$ of the water need of the crop. For irrigation management, carried out with the aid of the Irriger ${ }^{\circledR}$ application, we used temperature and relative air humidity, solar radiation, and wind speed data stemming from an automatic meteorological station located $4.0 \mathrm{~km}$ from the experimental area. in the harvest year of 2013/14, the sugarcane was cultivated without the use of irrigation.

The replenishment of water was performed from a selfpropelled irrigation bar of model Turbomaq 140/GSV/3504RII, with an application range of $54 \mathrm{~m}$, with a free span from the bar to the ground, varying between $1.0-4.0 \mathrm{~m}$. We used the LDN Spray-type sprinkler with Senninger \# 21 nozzles and 20 psi Senninger pressure regulator.

The experimental design used was of random blocks. The treatments consisted of fifteen commercial sugarcane varieties of distinct agronomic characteristics (Table 1), with four repetitions. The experimental parcels were composed of four lines, with $15 \mathrm{~m}$ of length and a spacing of $1.5 \mathrm{~m}\left(90 \mathrm{~m}^{2}\right)$. 
For the sugarcane productivity estimate, we used the Agro-Ecological Zone (AEZ) method - FAO Model (Doorenbos \& Kassam, 1979):

$\mathrm{PP}=\mathrm{PPB}_{\mathrm{P}} \cdot \mathrm{C}_{\mathrm{LAI}} \cdot \mathrm{C}_{\mathrm{R}} \cdot \mathrm{C}_{\mathrm{C}} \cdot \mathrm{C}_{\mathrm{M}} \cdot \mathrm{N}_{\mathrm{D}}$

where PP is the potential productivity ( $\mathrm{t} \mathrm{MS} \mathrm{ha-1} \mathrm{d}^{-1}$ ), $\mathrm{PPB}_{\mathrm{P}}$ is the gross photosynthetic yield of dry matter from a standard crop ( $\left.\mathrm{t} M S \mathrm{ha}^{-1} \mathrm{~d}^{-1}\right) ; \mathrm{C}_{\mathrm{LAI}}$ is the correction of the leaf area index (for $\mathrm{LAI}<5, \mathrm{C}_{\mathrm{LAI}}=$ $0.0093+0.185 \mathrm{LAI}-0.0175 \mathrm{LAI}^{2}$; and for $\mathrm{LAI} \geq 5, \mathrm{C}_{\mathrm{LAI}}$ $=0,5) ; \mathrm{C}_{\mathrm{R}}$ is the correction for breathing losses (maintenance and growth), (for $\mathrm{T}<20^{\circ} \mathrm{C}, \mathrm{C}_{\mathrm{R}}=0.6$; and for $\left.\mathrm{T} \geq 20^{\circ} \mathrm{C}, \mathrm{C}_{\mathrm{R}}=0.5\right) ; \mathrm{C}_{\mathrm{C}}$ is the correction for the harvested part of the crop, ( sugarcane $\left.\mathrm{C}_{\mathrm{C}}=0.75\right) ; \mathrm{C}_{\mathrm{M}}$ is the correction to consider the moisture of the harvested part (sugarcane $\mathrm{C}_{\mathrm{M}}=0.8$ ); and $\mathrm{N}_{\mathrm{D}}$ is the total period of the crop cycle (days).
The potential productivity of the second sugarcane ratoon was corrected due to the occurrence of a water deficit, thus obtaining an achievable productivity $(\mathrm{PR}, \mathrm{t}$ ha $\left.{ }^{1} \mathrm{~d}^{-1}\right)$ :

$\mathrm{PR}=\mathrm{PP} \cdot\left[1-\mathrm{K}_{\mathrm{y}} \cdot\left(1-\frac{\mathrm{ETR}}{\mathrm{ETc}}\right)\right]$

where $\mathrm{k}_{\mathrm{y}}$ is the factor of sensitivity to the water deficit of the crop in each development stage (adopting for sugarcane 0.75 ; 0.5 ; and 0.1 for the stages sprouting, establishment, and vegetative growth; crop formation; and maturation, respectively), ETR is the actual evapotranspiration ( $\mathrm{mm}$ $\left.\mathrm{d}^{-1}\right)$, and ETc is the crop evapotranspiration $\left(\mathrm{mm} \mathrm{d}^{-1}\right)$. The ETc was obtained through the product of the reference evapotranspiration (ETo, $\mathrm{mm} \mathrm{d}^{-1}$ ), determined using the Penman-Monteith method (Allen et al., 1998), with the crop coefficient (Table 2).

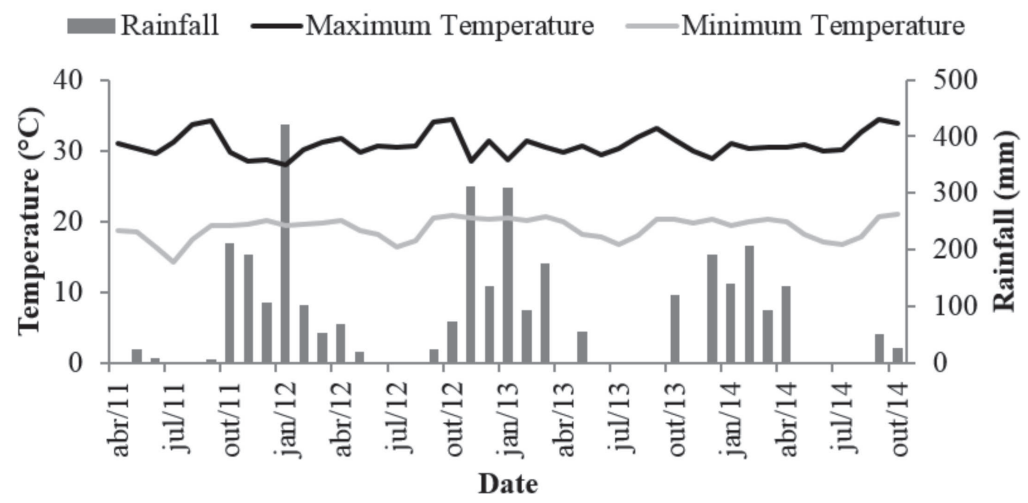

Figure 1: Maximum and minimum air temperatures and accumulated rainfall during the experiment, Goianésia, GO, Brazil.

Table 1: Agronomic information of sugarcane varieties used in the experiment

\begin{tabular}{|c|c|c|c|c|c|c|}
\hline \multirow{2}{*}{ Treatment } & \multirow{2}{*}{ Variety } & \multicolumn{5}{|c|}{ Varietal characteristics } \\
\hline & & Height & Average diameter & Tillering & Productivity & Cycle \\
\hline $\mathrm{T} 1$ & CTC2 & $\mathrm{M}^{*}$ & $\mathrm{M}$ & $\mathrm{M}$ & $\mathrm{H}$ & M \\
\hline Т 2 & CTC4 & $\mathrm{M}-\mathrm{H}$ & $\mathrm{F}-\mathrm{M}$ & M-H & $\mathrm{H}$ & M \\
\hline T 3 & CTC9 & M & M & M & M & $\mathrm{E}$ \\
\hline $\mathrm{T} 4$ & CTC11 & M & M & $\mathrm{H}$ & $\mathrm{H}$ & $\mathrm{M}-\mathrm{C}$ \\
\hline T 5 & CTC15 & M & M & $\mathrm{M}-\mathrm{H}$ & $\mathrm{H}$ & $\mathrm{M}-\mathrm{C}$ \\
\hline Т 6 & CTC18 & $\mathrm{H}$ & M & $\mathrm{M}-\mathrm{H}$ & M & E-M \\
\hline $\mathrm{T} 7$ & IAC87-3396 & M-H & M & M & M-H & E-M \\
\hline Т 8 & IAC91-1099 & M & M & $\mathrm{H}$ & $\mathrm{M}-\mathrm{H}$ & E-M \\
\hline Т 9 & IACSP94-2094 & $\mathrm{M}$ & $\mathrm{F}$ & $\mathrm{H}$ & M & $\mathrm{M}-\mathrm{C}$ \\
\hline T 10 & IACSP94-2101 & $\mathrm{M}-\mathrm{H}$ & F-M & M-H & M & $\mathrm{M}-\mathrm{C}$ \\
\hline $\mathrm{T} 11$ & IACSP95-5000 & $\mathrm{M}-\mathrm{H}$ & M & M & M-H & $\mathrm{M}-\mathrm{C}$ \\
\hline $\mathrm{T} 12$ & RB867515 & $\mathrm{H}$ & M & M & $\mathrm{H}$ & $\mathrm{M}-\mathrm{C}$ \\
\hline Т 13 & RB92579 & $\mathrm{H}$ & M & $\mathrm{H}$ & $\mathrm{H}$ & $\mathrm{M}-\mathrm{C}$ \\
\hline Т 14 & RB966928 & M & M & $\mathrm{H}$ & $\mathrm{H}$ & E-M \\
\hline T 15 & SP86-0042 & M & M & M & M & $\mathrm{M}-\mathrm{C}$ \\
\hline
\end{tabular}

*M: medium. H: high, M-H: medium to high, F: fine, F-M: fine to medium, E: early, C: coarse, E-M: early to medium, M-C: medium to coarse.

Source: Centro de Tecnologia Canavieira - CTC (2011), Landell et al. (2005, 2007), Rede Interuniversitária para o Desenvolvimento do Setor Sucroalcooleiro - RIDESA (2010), Copersucar (2003). 
The ETR was obtained through the daily sequential water balance (Thornthwaite \& Mather, 1955). For the daily sequential water balance, we used the value of the available water capacity (AWC) equal to $71.47 \mathrm{~mm}$, with this value having been obtained from physical-water analyses of the soil and Equation 3:

$\mathrm{AWC}=(\mathrm{FC}-\mathrm{PWP}) \cdot \mathrm{Z}$

where FC is field capacity $\left(\mathrm{cm}^{3} \mathrm{~cm}^{-3}\right), \mathrm{PWP}$ is permanent wilting point $\left(\mathrm{cm}^{3} \mathrm{~cm}^{-3}\right)$, and $\mathrm{Z}$ is average effective depth of the root system $(\mathrm{mm})$ of the sugarcane varieties studied ( $\mathrm{Z}=600 \mathrm{~mm}$ ).

The sugarcane harvest was performed mechanically, with the first cut occurring on September 7th, 2012, and the second and third cuts on September 13th, 2013, and October 16th, 2014, respectively. A crawler harvester (John Deere model 3510) was used and a transhipment truck with a high-flotation tire and a load cell device with a display positioned inside the truck cabin. The mass was determined from the harvest of each line. On the harvest date, ten industrialized cane stalks was collected for the determination of technological analyzis (Bidoia \& Bidoia, 2008). These stalks were cut, and sent to the laboratory. To determine the chemical parameters, Consecana's methodology (Conselho dos produtores de cana-de-açúcar, açúcar e etanol do Estado de São Paulo - Consecana, 2006) was used.

We performed an analysis of variance $(\alpha=0.05)$ on the productivity data of the different varieties, considering the cane-plant and ratoon cycles and only the ratoon cycles, and comparing the means using the Tukey test at $5 \%$ error probability. The performance of the results of the AEZ method was tested from Pearson's correlation coefficient (r), the root-mean-square error (RMSE), the mean absolute error (MAE), and the Willmott's agreement index (d). RMSE and MAE are used to measure the ability that numerical models have in reproducing reality, with values equal to zero indicating perfect simulation. As RMSE and MAE are little affected by outliers, they are considered precise and robust

Table 2: Values for the sugarcane ratoon crop coefficient (Kc)

\begin{tabular}{llc}
\hline $\begin{array}{c}\text { Crop age } \\
\text { (months) }\end{array}$ & \multicolumn{1}{c}{ Development Stage } & $\begin{array}{c}\text { Crop } \\
\text { Coefficient } \\
\text { (Kc) }\end{array}$ \\
\hline $0-1$ & From planting until 0.25 of cover & 0.55 \\
$1-2$ & From 0.25 to 0.50 of cover & 0.80 \\
$2-2.5$ & From 0.50 to 0.75 of cover & 0.90 \\
$2.5-4$ & From 0.75 until complete cover & 1.00 \\
$4-10$ & Maximum utilization & 1.05 \\
$10-11$ & Beginning of maturation & 0.80 \\
$11-12$ & Maturation & 0.60 \\
\hline
\end{tabular}

Source: Allen et al. (1998). measures. Another advantage is that they have the same dimensions as the analyzed variable (Fox, 1981). Willmott's agreement index expresses the quality of the adjustment (accuracy) which is related to the approximation of the estimated values in relation to those observed. Their values range from zero to 1 indicating no agreement and perfect agreement, respectively (Willmott, 1985). Also, we determined the error (E, \%) among the observed $\left(\mathrm{v}_{\mathrm{o}}\right)$ and estimated $\left(\mathrm{v}_{\mathrm{e}}\right)$ values:

$\mathrm{E} \%=\frac{\left|\mathrm{V}_{\mathrm{O}}-\mathrm{V}_{\mathrm{e}}\right|}{\mathrm{V}_{\mathrm{o}}} \cdot 100$

\section{RESULTS AND DISCUSSION}

From the analysis of variance of the productivities, one may observe that the varieties did not statistically differ among themselves ( $p>0.05)$ in terms of productivity, for all the cycles investigated.

Campos et al. (2014a) recommend the cultivation of varieties IAC91-1099 and CTC15 in a regime of supplementary irrigation, for the Cerrado region, for presenting satisfactory productivity and industrial yield. Silva et al. (2014) assessed the agroindustrial productive potential of eight sugarcane varieties irrigated during two harvest years in the area of Jaú, SP, Brazil, and found that, among other cultivars, IAC91-1099 stood out positively in terms of productivity. In the second cut, the variety presented productivity over $115 \mathrm{t} \mathrm{ha}^{-1}$ for the one-year cycle.

The potential productivity values of sugarcane for the plant, first ratoon, and second ratoon cycles were estimated through the AEZ method and compared with the average productivities (Figure 2), and its performance was tested (Table 3).

The AEZ method overestimated the potential productivity values for the plant cycle (one-and-a-halfyear sugarcane) in all varieties investigated, while for the ratoon cycles (one-year cycles), the estimated productivity values came close those observed in the field, with such data approximating the 1:1 line (Figure 2).

The variety that resulted in the most significant discrepancy in its productivity values estimated by the AEZ method was CTC18, presenting an RMSE of $100.32 \mathrm{t}$ $\mathrm{ha}^{-1}$ and an MAE of $76.74 \mathrm{tha}^{-1}$. In turn, the data estimated for CTC15 were those that best fit (RMSE $=60.07 \mathrm{t} \mathrm{ha}^{-1}$ and MAE $=40.37 \mathrm{t} \mathrm{ha}^{-1}$ ) (Figure 2). This amplitude in the estimate observed from the calculation of the errors may not be interesting since it does not collaborate with decision-making in production processes. Despite the errors having been considered high, according to the Pearson coefficients the data estimated correlated satisfactorily with those observed and also presented performance varying from good to excellent according to Willmott's agreement index (Willmott et al., 1985). Such

Rev. Ceres, Viçosa, v. 68, n.1, p. 001-009, jan/feb, 2021 
results reinforce the importance of evaluating the performance of the productivity estimation model in relation to the productivity data obtained in the field based on different statistical indices.

To determine if there was a significant difference between the productivity data estimated by the AEZ method and those observed, we performed the analyses of variance. We observed that the values observed did not statistically differ from those estimated $(\mathrm{p}>0.05)$, thus corroborating with Willmott's agreement index.

Although it is a generic model, the AEZ method has been used in different studies as a sugarcane harvest forecasting tool (Marin \& Carvalho 2012; Gouvêa et al., 2009), presenting results of quite satisfactory estimates.

Marin \& Carvalho (2012) evaluated the performance of the sugarcane crop in the state of São Paulo, Brazil, through the potential productivity estimation model of AEZ and stated that such application may be used as a strategic tool in the agricultural sector, contributing for better taking advantage of the productive potential of the crop, given that it contributes to the definition of areas and varieties more suitable for a given region.

Although the analysis of variance, the Pearson coefficient, and the agreement index point to a reasonable
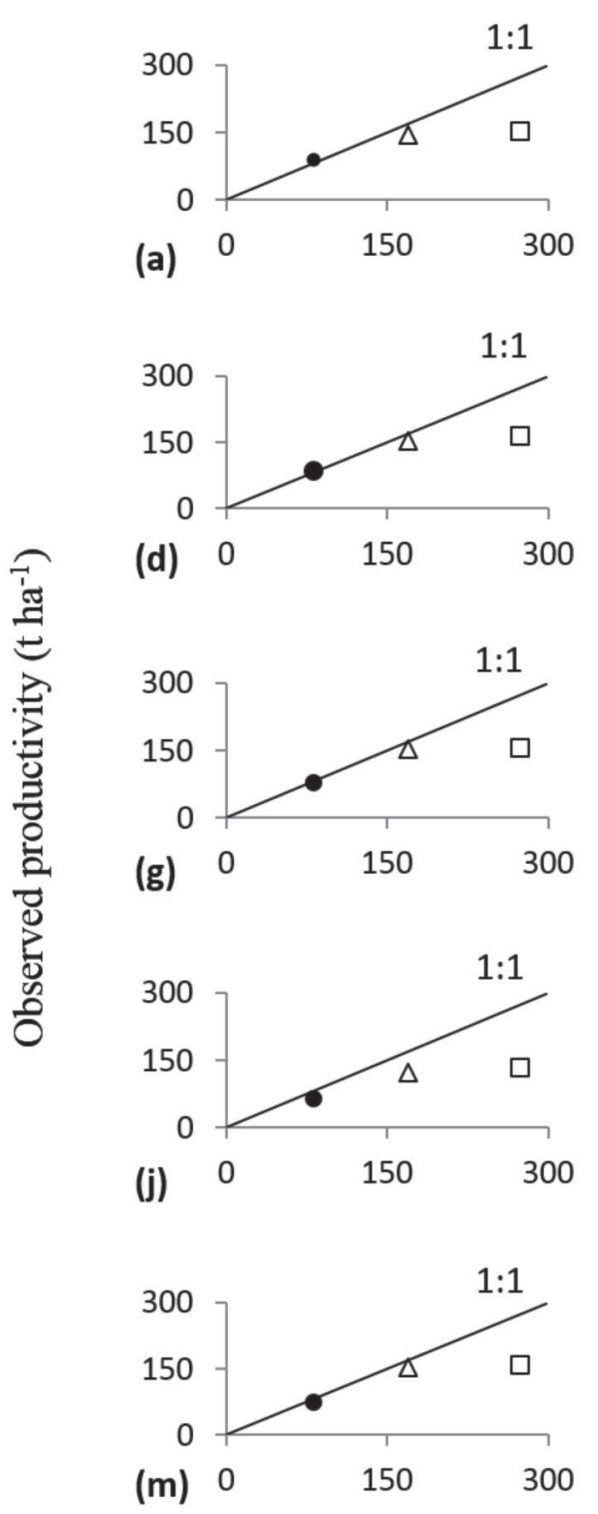
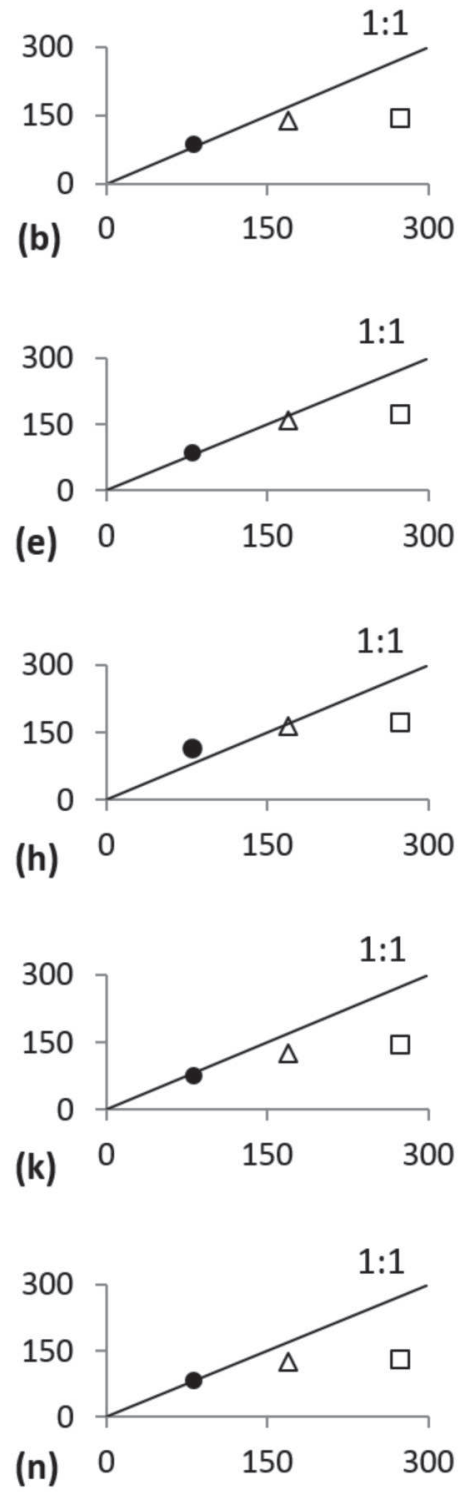

Estimated productivity $\left(\mathrm{t} \mathrm{ha}^{-1}\right)$
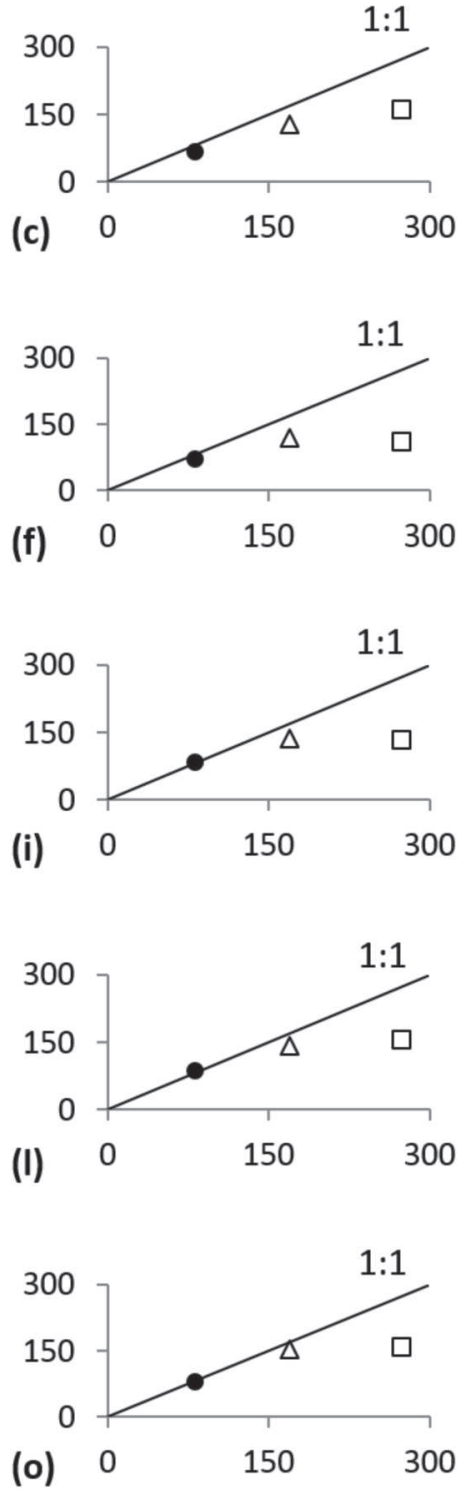

(i) 0

(o) 0 300

Figure 2: Relations among the productivities estimated by the Agro-Ecological Zone method and those observed for varieties CTC2 (a), CTC4 (b), CTC9 (c), CTC11 (d), CTC15 (e), CTC18 (f), IAC87-3396 (g), IAC91-1099 (h), IACSP94-2094 (i), IACSP94-2101 (j), IACSP95-5000 (k), RB867515 (1), RB92579 (m), RB966928 (n), and SP86-0042 (o) in the cane-plant cycle (ם) and the first ( $\Delta$ ) and second $(\bullet)$ cycles of sugarcane ratoon, Goianésia, GO, Brazil. 
adjustment of the model to the data, the values obtained by the AEZ method for the cane-plant cycle (one-and-ahalf-year sugarcane) are overestimated (Figure 2), leading to the imprecision in the estimates. For the plant cycle, we found errors (Table 4) varying from $60.5 \%$ (CTC15 variety) to $151.6 \%$ (CTC18).

Caetano \& Casaroli (2017) used the standard AEZ method with adjustments considering water deficit and productivity loss to estimate the productivity of sugarcane (cane-plant and cane-ratoon cycles) in Santo Antônio de Goiás (Goiás, Brazil). The results were also overestimated with RMSE and MAE ranging from 14.2 to $46.1 \mathrm{tha}^{-1}$ and 13.9 to $45.6 \mathrm{tha}^{-1}$.

One hypothesis to justify the overestimation of the productivity obtained by the AEZ method for the oneand-a-half-year sugarcane is the fact that the model considers the total period of the crop cycle in days and assumes that, in this period, the plant accumulates dry matter. However, in the phenological phase of maturation of sugarcane, an intense accumulation of dry matter does not occur because the rate of vegetative growth is little expressive compared to the other stages (Santos et al., 2015). We emphasize that the duration of the maturation phase in the one-and-a-half-year sugarcane is of around sixty days, while in the one-year cycle this phenological phase is smaller, of approximately thirty days (Doorenbos \& Kassam, 1979). Hence, the overestimations are more propitious to occur in the one-and-a-half-year sugarcane.

The vegetative growth of sugarcane is restricted in the maturation phase because the photoassimilate (sucrose) required for the expansion of the plant tissues is translocated to be stored in the stems. We stress that the natural maturation of sugarcane requires a water deficit and/or temperatures below $20{ }^{\circ} \mathrm{C}$ (Cardozo \& Sentelhas, 2013).

Still, this overestimation was expected for both the cycles and may be associated with the fact that only the water deficiency is the limiting factor of productivity, not considering other factors that are important in determining the crop productivity such as diseases, pests, nutritional shortages, and improper management (Doorenbos \& Kassam, 1979),

Therefore, we performed new statistical analyses considering only the ratoon cycles (one-year cycles), finding expressively smaller errors (\%) (Table 4).

Table 4: Error of the values estimated in relation to those observed (E, \%) for the sugarcane cultivars for the cane-plant cycle and the first and second cycles of the sugarcane ratoon

\begin{tabular}{lrcr}
\hline \multirow{2}{*}{ Variety } & \multicolumn{3}{c}{ Sugarcane cycle } \\
\cline { 2 - 4 } & Plant & $\mathbf{1}^{\text {st }}$ ratoon & $\mathbf{2}^{\text {nd }}$ ratoon \\
\hline CTC2 & $79.8 \%$ & $19.1 \%$ & $10.9 \%$ \\
CTC4 & $94.2 \%$ & $23.4 \%$ & $6.6 \%$ \\
CTC9 & $73.5 \%$ & $33.8 \%$ & $17.3 \%$ \\
CTC11 & $68.0 \%$ & $10.2 \%$ & $7.6 \%$ \\
CTC15 & $60.5 \%$ & $9.5 \%$ & $4.1 \%$ \\
CTC18 & $151.6 \%$ & $47.4 \%$ & $15.9 \%$ \\
IAC87-3396 & $76.4 \%$ & $11.2 \%$ & $0.5 \%$ \\
IAC91-1099 & $62.1 \%$ & $2.6 \%$ & $26.8 \%$ \\
IACSP94-2094 & $108.8 \%$ & $24.2 \%$ & $1.7 \%$ \\
IACSP94-2101 & $110.2 \%$ & $43.8 \%$ & $29.5 \%$ \\
IACSP95-5000 & $89.0 \%$ & $38.7 \%$ & $8.3 \%$ \\
RB867515 & $76.3 \%$ & $23.0 \%$ & $5.4 \%$ \\
RB92579 & $74.1 \%$ & $12.4 \%$ & $6.6 \%$ \\
RB966928 & $109.7 \%$ & $35.0 \%$ & $3.2 \%$ \\
SP86-0042 & $74.1 \%$ & $11.1 \%$ & $0.7 \%$ \\
\hline
\end{tabular}

Table 3: Coefficients of Pearson's correlation ( $r)$, root-mean-square error (RMSE, $\left.t \mathrm{tha}^{-1}\right)$, mean absolute error $\left(\mathrm{MAE} \mathrm{t}\right.$ ha $\left.{ }^{-1}\right)$, and Willmott's agreement index (d) of the sugarcane cultivars for the cane-plant cycle and for the first and second cycles of sugarcane ratoon

\begin{tabular}{lcccc}
\hline Variety & RMSE & MAE & d & r \\
\hline CTC2 & 71.98 & 52.77 & 0.84 & 0.9119 \\
CTC4 & 78.81 & 56.80 & 0.81 & 0.8706 \\
CTC9 & 71.58 & 56.84 & 0.87 & 0.9762 \\
CTC11 & 64.60 & 44.30 & 0.88 & 0.8949 \\
CTC15 & 60.07 & 40.37 & 0.90 & 0.9211 \\
CTC18 & 100.32 & 76.74 & 0.70 & 0.7641 \\
IAC87-3396 & 69.04 & 45.26 & 0.87 & 0.8569 \\
IAC91-1099 & 62.84 & 46.20 & 0.86 & 0.8686 \\
IACSP94-2094 & 84.39 & 58.93 & 0.78 & 0.7865 \\
IACSP94-2101 & 88.54 & 71.09 & 0.80 & 0.9208 \\
IACSP95-5000 & 79.21 & 60.73 & 0.82 & 0.9689 \\
RB867515 & 70.73 & 51.53 & 0.85 & 0.9465 \\
RB92579 & 68.06 & 46.65 & 0.88 & 0.8768 \\
RB966928 & 86.36 & 63.19 & 0.76 & 0.8882 \\
SP86-0042 & 67.84 & 44.57 & 0.87 & 0.8681 \\
\hline
\end{tabular}

Rev. Ceres, Viçosa, v. 68, n.1, p. 001-009, jan/feb, 2021 
When performing the analyses considering only the sugarcane ratoon cycles, we found a better adjustment of the estimated values to those obtained in the field (Figure 3), obtaining better performance of the AEZ method (Table 5). Again, variety CTC15 obtained the best estimate value $\left(\mathrm{RMSE}=8.70 \mathrm{tha}^{-1} ; \mathrm{MAE}=6.05 \mathrm{tha}^{-1}\right)$, and the productivity estimate for CTC18 was the least satisfactory (RMSE = $32.12 \mathrm{t} \mathrm{ha}^{-1}$; MAE $\left.=21.87 \mathrm{t} \mathrm{ha}^{-1}\right)$. According to the agreement index (d), the AEZ method obtained excellent performance $(d>0.85)$ for the estimation of productivity for all varieties except CTC18, whose performance was very $\operatorname{good}(0.76<\mathrm{d} \leq 0.85)$, according to Willmott et al. (1985).
The analyses of variance of the estimated and observed productivities in the first and second ratoon cycles (both one-year cycles) indicated there was no significant difference between them, with the p-values being higher than the significance level adopted ( $p>0.05)$. Hence, one may state that the AEZ method presented good results of estimated productivity for all sugarcane varieties investigated.

Oliveira et al. (2012b) studied the AEZ method for the macroregion of the Triângulo Mineiro, Brazil, for productivity data of plant and first-cut ratoon, isolatedly, finding that the AEZ method presented a satisfactory adjustment for the first ratoon cycle, explaining $89 \%$ of

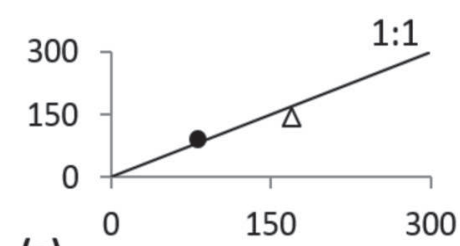

(a)
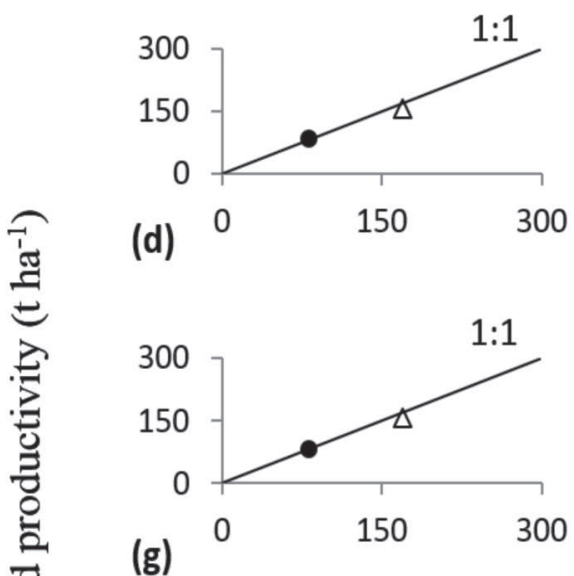

(g)
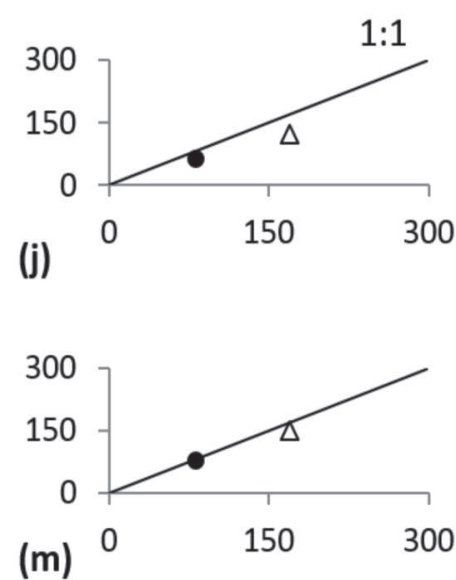

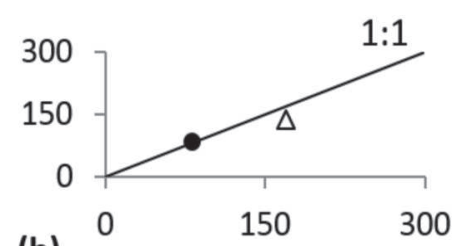

(b)

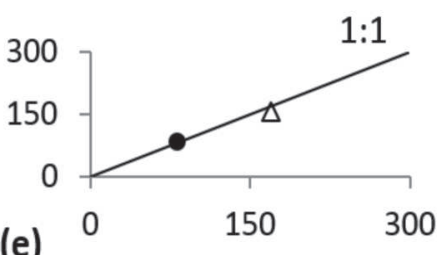

$1: 1$

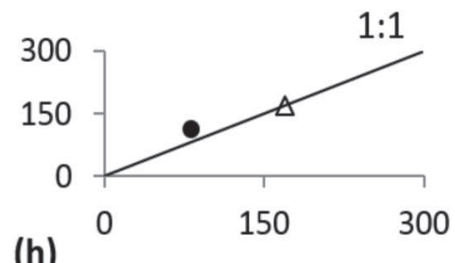

(h)
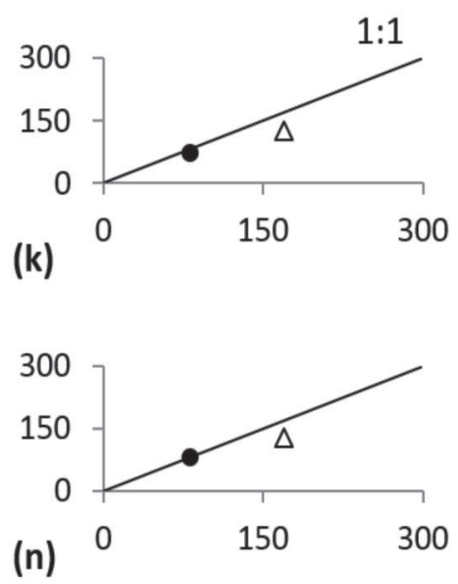

Estimated productivity $\left(\mathrm{t} \mathrm{ha}{ }^{-1}\right)$

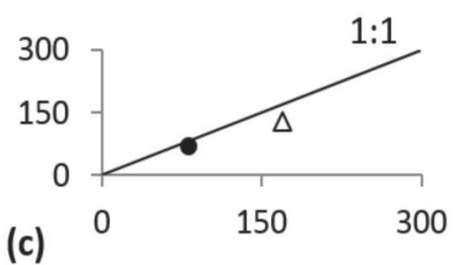

$1: 1$

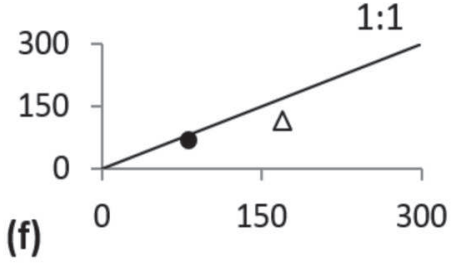

$1: 1$

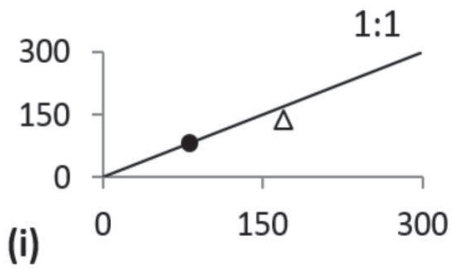

$1: 1$
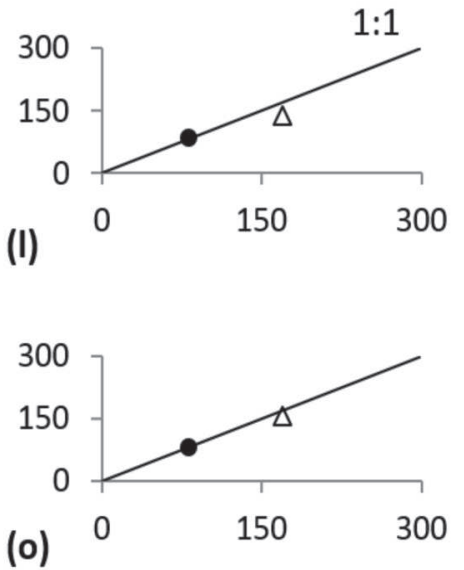

(o) 300

Figure 3: Relations among the productivities estimated by the Agro-Ecological Zone method and those observed for varieties CTC2 (a), CTC4 (b), CTC9 (c), CTC11 (d), CTC15 (e), CTC18 (f), IAC87-3396 (g), IAC91-1099 (h), IACSP94-2094 (i), IACSP94-2101 (j), IACSP95-5000 (k), RB867515 (1), RB92579 (m), RB966928 (n), and SP86-0042 (o) for the first ( $\Delta$ ) and second (•) cycles of sugarcane ratoon, Goianésia, GO, Brazil. 
Table 5: Coefficients of the root-mean-square error (RMSE, $t$ ha $^{-1}$ ), mean absolute error (MAE, t ha ${ }^{-1}$ ), and Willmott's agreement index (d) for the sugarcane cultivars for the first and second cycles of sugarcane ratoon

\begin{tabular}{lrrc}
\hline Variety & RMSE & MAE & d \\
\hline CTC2 & 16.69 & 12.35 & 0.96 \\
CTC4 & 18.86 & 12.62 & 0.94 \\
CTC9 & 25.68 & 18.26 & 0.91 \\
CTC11 & 9.82 & 7.44 & 0.99 \\
CTC15 & 8.70 & 6.05 & 0.99 \\
CTC18 & 32.12 & 21.87 & 0.83 \\
IAC87-3396 & 9.83 & 5.81 & 0.99 \\
IAC91-1099 & 17.34 & 11.33 & 0.96 \\
IACSP94-2094 & 19.07 & 11.47 & 0.95 \\
IACSP94-2101 & 31.64 & 23.35 & 0.85 \\
IACSP95-5000 & 27.55 & 17.85 & 0.88 \\
RB867515 & 18.52 & 12.12 & 0.95 \\
RB92579 & 11.17 & 7.89 & 0.99 \\
RB966928 & 25.43 & 15.54 & 0.89 \\
SP86-0042 & 9.75 & 5.81 & 0.99 \\
\hline
\end{tabular}

the variability of the data observed in the field. The accuracy of the method for the first ratoon $(\beta=0.90)$ and the precision $\left(\mathrm{R}^{2}=0.89\right)$ were superior to those for the cane-plant.

Barbieri \& Silva (2008) adjusted the AEZ method to predict the monthly accumulation of dry matter of sugarcane considering the one-year cycle and verified a linear relation among the observed and estimated values with a determination coefficient $\left(\mathrm{R}^{2}\right)$ equal to 0.9458 .

\section{CONCLUSION}

For the cultivation conditions adopted, the sugarcane varieties did not show significant difference in productivity.

The Agro-Ecological Zone method may be recommended for the estimation of sugarcane productivity in the Cerrado region for all fifteen varieties studied, presenting, however, better results in cane fields with oneyear cycles.

Considering the all fifteen varieties studied, the agrometeorological model of the Agro-Ecological Zone method estimated the sugarcane productivity of the Cerrado region more satisfactory for variety $\mathrm{CTC} 15$.

\section{REFERENCES}

Allen RG, Pereira LS, Raes D \& Smith M (1998) Crop evapotranspiration - guidelines for computing crop water requirements. Rome, FAO. 56p.

Araújo R, Alves Júnior J, Casaroli D \& Evangelista AWP (2016) Variation in the sugar yield in response to drying-off of sugarcane before harvest and the occurrence of low air temperatures. Bragantia, 75:118-127.
Barbieri V \& Silva FC (2008) Adequação do Método da Zona Agroecológica (FAO) para estimativa do acúmulo mensal potencial de matéria seca da cana-de-açúcar (Saccharum spp.) e da produtividade agrícola para diferentes condições climáticas. Sociedade dos Técnicos Açucareiros e Alcooleiros do Brasil STAB, 26:47-50.

Bidoia MAP \& Bidoia MAP (2008) Experimentação com canade-açúcar. In: Dinardo-Miranda LL, Vasconcelos ACM \& Landell MGA (Ed.) Cana-de-açúcar. $1^{\text {st }}$ ed. Campinas, Instituto Agronômico. p. 809-819.

Braga Júnior RLC, Landell MGA, Silva DN, Bidoia MAP, Silva TN, Thomazinho Júnior JR, Silva VHP \& Anjos IA (2019) Censo varietal IAC de cana-de-açúcar no Brasil - Safra 2017/18 e na região Centro Sul - Safra 2018/19. Campinas, Instituto Agronômico. 64p. (Boletim Técnico, 221).

Bull TA \& Tovey DA (1974) Aspects of modeling sugarcane growth by computer simulation. In: International Society Sugarcane Technologists 15, Durban. Proceedings, ISSCT. p.1021-1032.

Caetano JM \& Casaroli D (2017) Sugarcane yield estimation for climatic conditions in the center of state of Goiás. Revista Ceres, 64:298-306.

Campos PF, Alves Júnior J, Casaroli D, Fontoura PR \& Evangelista AWP (2014a) Variedades de cana-de-açúcar submetidas à irrigação suplementar no cerrado goiano. Engenharia Agrícola, 34:1139-1149.

Campos PF, Alves Júnior J, Casaroli D, Fontoura PR, Evangelista AWP \& Vellame LM (2014b) Response of sugarcane varieties to deficit irrigation in Brazilian Savanna. Water Resources and Irrigation Management, 3:31-36.

Cardozo NP \& Sentelhas PC (2013) Climatic effects on sugarcane ripening under the influence of cultivars and crop age. Scientia Agricola, 70:449-456.

Centro de Tecnologia Canavieira - CTC (2011) Bula Técnica Variedades CTC. Available at: https://www.scielo.br/revistas/ rceres/pinstruc.htm. Accessed on: December $6^{\text {th }}, 2020$.

Companhia Nacional de Abastecimento - Conab (2020) Acompanhamento da safra brasileira de cana-de-açúcar. Available at: http://www.conab.gov.br. Accessed on: December 6 ${ }^{\text {th }}, 2020$.

Conselho dos produtores de cana-de-açúcar, açúcar e etanol do Estado de São Paulo - Consecana (2006) Manual de Instruções. $5^{\text {th }}$ ed. Piracicaba, Consecana. 112p.

Doorenbos J \& Kassam AH (1979) Yield response to water. Rome, FAO. $172 \mathrm{p}$.

Empresa Brasileira de Pesquisa Agropecuária - Embrapa (2006) Sistema brasileiro de classificação de solos. $2^{\text {nd }}$ ed. Rio de Janeiro, Embrapa/SPI. 306p.

Fox DG (1981) Judging air quality model performance. Bulletin of the American Meteorological Society, 62:599-609.

Gouvêa JRF, Sentelhas PC, Gazzola ST \& Santos MC (2009) Climate changes and technological advances: Impacts on sugarcane productivity in tropical Southern Brazil. Scientia Agricola, 66:593-605.

Inman-Bamber NG, Muchow RC \& Robertson MJ (2002) Dry matter partitioning of sugarcana in Australia and South Africa. Field Crops Research, 76:71-84.

Landell MGA, Campana MP, Figeuiredo P, Vasconcelos ACM, Xavier MA, Bidoia MAP, Prado H, Silva MA, Dinardo-Miranda LL, Santos ASS, Perecin D, Rossetto R, Silva DN, Martins ALM, Gallo PB, Kanthack RAD, Cavichioli JC, Veiga Filho AA, Anjos IA, Azania CAM, Pinto LR \& Souza SC (2005) Variedades de cana-de-açúcar para o Centro-Sul do Brasil: 15 a liberação do programa cana IAC (1959 - 2005). Campinas, Instituto Agronômico. 33p. (Boletim Técnico, 197). 
Landell MGA, Campana MP, Figueiredo P, Vasconcelos ACM, Xavier MA, Bidoia MAP, Silva DN, Anjos IA, Prado H, Pinto LR, Souza SCD, Scarpari MS, Rosa Junior VE, Dinardo-Miranda LL, Azania CAM, Perecin D, Rossetto R, Silva MA, Martins ALM, Gallo PB, Kanthack RAD, Cavichioli JC, Veiga Filho AA, Mendonça JR, Dias FLF \& Garcia JC (2007) Variedades de canade-açúcar para o Centro-Sul do Brasil: $16^{a}$ liberação do programa cana IAC (1959 - 2007). Campinas, Instituto Agronômico. 35p. (Boletim Técnico, 201).

Loarie SR, Lobell DB, Asner GP, Mu Q \& Field CB (2011) Direct impacts on local climate of sugar-cane expansion in Brazil. Nature Climate Change, 1:105-109.

Marafon AC (2012) Análise quantitativa de crescimento em canade-açúcar: uma introdução ao procedimento prático. Aracaju, Embrapa Tabuleiros Costeiros. 29p.

Marin FR \& Carvalho GL (2012) Spatio-temporal variability of sugarcane yield efficiency in the state of São Paulo, Brazil. Pesquisa Agropecuária Brasileira, 47:149-156.

Marin FR \& Nassif DSP (2013) Mudanças climáticas e a cana-deaçúcar no Brasil: Fisiologia, conjuntura e cenário futuro. Revista Brasileira de Engenharia Agrícola e Ambiental, 17:232-239.

Monteiro LA (2012) Modelagem agrometeorológica como base para a definição de ambientes de produção para a cultura da cana-de-açúcar no estado de São Paulo. Dissertação de Mestrado. Escola Superior de Agricultura Luiz de Queiroz, Piracicaba. 116p.

Oliveira SD, Silva VPR, Santos CAC, Silva MT \& Sousa EP (2012a) Os Impactos das alterações climáticas na cana-de-açúcar cultivada em Sistema de sequeiro na Região Nordeste do Brasil. Revista Brasileira de Geografia Física, 5:170-184.

Oliveira RA, Santos RS, Ribeiro A, Zolnier S \& Barbosa MHP (2012b) Estimativa da produtividade da cana-de-açúcar para as principais regiões produtoras de Minas Gerais usando-se o método ZAE. Revista Brasileira de Engenharia Agrícola e Ambiental, $16: 549-557$.
Rede Interuniversitária para o Desenvolvimento do Setor Sucroalcooleiro (2010) Catálogo nacional de variedades "RB" de cana-de-açúcar. Curitiba, Ridesa. 136p.

Santos CM, Silva MA, Lima GPP, Bortolheiro FPAP, Brunelli MC, Holanda LA \& Oliver R (2015) Physiological changes associated with antioxidant enzymes in response to sugarcane tolerance to water deficit and rehydration. Sugar Tech, 17:291304.

Scarpari MS \& Beauclair EGF (2009) Physiological model to estimate the maturity of sugarcane. Scientia Agricola, 66:622628.

Silva AA \& Miziara F (2011) Avanço do setor sucroalcooleiro e expansão da fronteira agrícola em Goiás. Pesquisa Agropecuária Tropical, 41:399-407.

Silva MA, Arantes MT, Rhein AFL, Gava GJC \& Kolln OT (2014) Potencial produtivo da cana-de-açúcar sob irrigação por gotejamento em função de variedades e ciclos. Revista Brasileira de Engenharia Agrícola e Ambiental, 18:241-249.

Singels AK \& Donaldson RA (1998) A simple model for unstressed canopy development. Proceeding of the South African Sugar Technology Association, 74:151-154.

Thompson GD (1976) Water use by sugarcane. South African Sugar Journal, 60:593-600.

Thornthwaite CW \& Mather JR (1955) The water balance. New Jersey, Drexel Institute of Technology. 104p.

Willmott CJ, Ackleson SG, Davis RE, Feddema JJ, Klink KM, Legates DR, O'donnell J \& Rowe CM (1985) Statistics for the evaluation and comparison of models. Journal of Geophysical Research, 90:8995 9005. 